\title{
Prinsen af Nør i Rendsborg fæstning
}

\section{Af Hans Neerbek.}

I "Sønderjydske Årbøger«, 1937 offentliggjorde overarkivar Holger Hjelholt sit indlæg fra historikerkonkurrencen året før: "Om dannelsen af den provisoriske regering. " Han behandlede her det, han kaldte: "Spørgsmålet om, hvorfor Prinsen af Nør tog sin gamle militærfrakke med «, d. v. s. om, hvorvidt prinsens deltagelse i kuppet i Rendsborg var fremkaldt af tilfældigheder eller ej, og drog forsigtige, men umiskendelige konklusioner ud fra de samtidige kilder.

Der er det ene beklagelige ved det friske lille arbejde, at Hjelholt standser op uden for Rendsborgs volde, altså ikke fortsætter med undersøgelsen af sandhedsværdien i prinsens beretning, da han er kommet inden for hovedvagten. Også her gemmer der sig nemlig ganske artige småting, således i kildernes uoverensstemmelse med hensyn til kommandantens rolle, om der blev slået generalmarch o. s. v. Jeg har valgt at søgge at belyse en enkelt, ganske lille tildragelse - som dog har haft sin betydning.

I 1948, i hundredåret for martsdagene, skildrede Bokkenheuser og Hatting i "Det begyndte i 48 « også kuppet i Rendsborg og efter at have refereret prinsens tale om den "ufrie konge" 0 . s. v. siger de: "En officer spurgte ham, hvorfra han havde disse nyheder. Prinsen svarede, at de stod i "Statstidende«, men blev afbrudt med, at en sådan ikke eksisterede. Han rettede det så til "Berlingske Tidende«, hvortil premierløjtnant Chr. Mathiesen råbte: „Det er løg n! «") I Fabricius' Danmarkshistorie står om den samme hændelse: "Kun de danske officerer med løjtnant Mathiesen i spidsen protesterede mod

1) K. Bokkenheuser og J. Hatting: »Det begyndte i $48 \ll, \mathrm{Kbhvn}, 1948$, p. 100. (Udhævelserne af mig). 


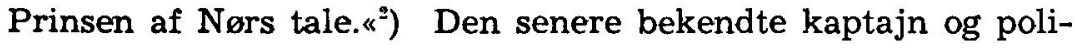
tiker C. Jagd fortæller, at hans chef på et vist tidspunkt var *Chr. Mathiesen, den officer, der i Rendsborg ved oprørets udbrud 1848 til Prinsen af Noer havde sagt: "Det er løgn« dengang prinsen erklærede, at den danske konge ikke var fri, og at der ingen regjering var $\mathrm{i}$ landet $\aleph^{3}$ )

Denne opfattelse af, hvad der hændte mellem prinsen og de danske officerer er der da også god hjemmel for hos et øjenvidne, den senere oberst Wedege, der som ung officer lå i Rendsborg i 1848, og som i ugebladet "Dannebrog " 1882 fortæller: "Der udspandt sig nu et ordskifte, idet prinsen gjentog historien om kongens ufrihed, medens lieutenant Chr. Mathiesen af 5. bataillon - ved hvis side jeg netop stod - protesterede. Prinsen påstod, at det stod $\mathbf{i}$ "Statstidende * for $\mathbf{i}$ går. Mathiesen: *Der existerer ingen "Statstidende«; hvis det skal være "Berlingske Tidende«, da kan det heller ikke være sandt, da denne ikke kan være kommet hertil endnu. "Det endte med, at prinsen udbrød: : Ja, hvad enten det nu er i "Statstidenden « eller i et andet blad, så have de herrer øjeblikkelig at begive sig til deres kvarterer og forblive der til nærmere ordre. $\kappa^{4}$ )

En fælleserklæring afgivet af nogle danske officerer (Krieger, Ernst m. fl.) d. 28. 3. 48 gengiver prinsens udtalelser om kongens ufrihed som ovnf., men fortsætter: »Den største del af officererne - - forlangte af prinsen at se en kongelig ordre, idet han bestandig påstod, at han handlede i kongens navn. Til svar herpå sagde han: »Mine herrer, De kunne jo læse det $i$ aviserne $\left.{ }^{\circ}{ }^{5}\right)$

Men hvad siger nu parterne selv i sagen? Her er vi så heldige at have en redegørelse fra Chr. Mathiesen, også nedskrevet kort efter og hvori det hedder: $\gg \mathrm{Da}$ Prindsen af Augustenborg havde gjort en fremstilling af de begivenheder, der skulle have bevirket den provisoriske regjerings sammentrædelse, og navn-

2) A Fabricius: Illustrenet Danmarkshistorie for Folket《. 4. udg. 1915, II p. 588.

3) K. B. Jagd: \Jagds gule Kanariefugle«, (duplikeret) 1950, p. 187.

4) „Danebrog\&, Ugeblaad for Hær og Flådle, 2. årg. nr 26 (p. 404).

6) Otto Vaupell: Lessøes Levned og Aktstykker til Krigen 184850«. Kbhvn. 1895, adststykker, p. 49. 
ligen at kongen var fangen, og dette ingenlunde stemmede med, hvad der berettedes i det sidste $\mathrm{nr}$. af Berlingske Tidende, hvorcfter Hs. Majestæt meget mere havde forekommet begjæringen om det ældre ministeriums entledigelse, henvendte jeg mig til prindsen med den bemærkning: "Das ist doch nur auf ein $\mathrm{Ge}-$ rücht, dass die provisorische Regierung sich die Macht genommen hat «, hvortil prindsen svarede: Das steht ja in der Staatszeitung, « hertil bemærkede jeg atter: "Ich kenne keine Staatszeitung " og ytrede prindsen: "oder in der Berilingschen Zeitung «, hvorpå han vendte sig om til den anden side og blev ved at tale, medens jeg, forbavset over den frækhed, med hvilken sådan usandhed fremførtes, ikke kunne tilbageholde det ud-

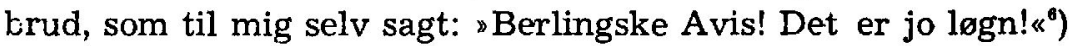

Som man vil have set, er der én tydelig uoverensstemmelse mellem Wedeges og Mathiesens forklaringer. Wedege hævder nemlig, at når Mathiesen sagde: "Løgn«, var det fordi "Berlingske Tidende« ikke kunne være nået dertil endnu, mens Mathiesen selv siger, at prinsens udtalelser ikke stemte med, hvad der faktisk stod i avisen.

$\mathrm{Nu}$ ved vi jo fra Hjelholts artikel, at "Berlingske Tidende» for 22. marts allerede d. 23. om morgenen i hvert fald var nået frem til Esselbachs gæstgivergård. (Beselers brev til broderen 23. 3. 73). Det er vel værd at erindre sig, at bladet ikke var tilhænger af den politiske retning, der var kommet til magten i København, og derfor ikke kan antages at være for elskværdig i sin bedømmelse af de stedfundne begivenheder, men $i$ artiklen herom - som ikke er lang og står inde $\mathrm{i}$ bladet - hedder det kun, at "alt foregik i den sterste rolighed, og ordenen blev ikke i mindste måde forstyrret«, og af kongens udtalelser, som er gengivet, fremgår det jo tydeligt, at hans onsker er i samklang med de liberales, at han altså handlede frit. Ikke desto mindre er det på denne avisartikel, at prinsen alene kan have bygget sin opfattelse, af hvad der var sket, da han får den refereret (cfr. Hijelholt).

Med hensyn til førnævnte uoverensstemmelse må Wedege altså have husket fejl, da han i 1882 skrev sine erindringer i

๑) ibidem, p. $46 \mathrm{ff}$. 
«Dannebrog «. Men hvad har nu Prinsen af Nør at sige til den anklage, der her er rettet mod ham for usandfærdighed?

Tilsyneladende mangler hans ord ikke noget $\mathrm{i}$ tydelighed: "- - jeg skulle have foreviist en avis, $i$ hvilken en artikel fra Kjøbeinhavn havde beskrevet revolutionen der og erklæret kongen for en fange. Denne opfindelse er altfor tåbelig til, at et nogenlunde forstandigt menneske ikke let kunne indse sammes umulighed. Hvorfra skulle jeg kunne have fået et sådant fabrikat? Og hvorledes skulle jeg kunne have gjort det, da jeg først den foregående dags eftermiddag kl. 5 kunne have kjendt begivenhederne i K.? På Noer var der intet trykkeri, og ligesålidt kunne jeg i Kiel få tid til sligt «.7)

Som man vil bemærke, drejer sagen sig her på én gang om helt andre ting end det $\mathrm{i}$ det foregående nævnte; nu skal prinsen pludselig have haft en avis med (i baglommen på generalsfrakken?) og det ovenikøbet en til lejligheden specielt fremstillet. Man kan næppe i dette tilfælde nå længere ved en undersøgelse af de direkte kilder.

Det kunne dog måske være lønnende et øjeblik at betragte den "psykologiske" side af sagen for indirekte at prøve at slutte sig til, hvem der har ret. Prinsens karakter er vel i hovedsagen kendt nok, men det kan være ganske oplysende at høre denne lille optegnelse (af en meget moderat helstatsmand) fra Chr. 8.s kroning 1840: "Det frembød nogen vanskelighed at passere forbi bag om alteret, hvorover nogle bleve utålmodige, og prindsen af Augustenborg, der som sædvanlig var "vorlaut«, råbte højt: "Vorwärtz! « Landgreve Vilhelm søgte at berolige ham. "Nej, vi må frem, lad mig «, og nu skred han frem meld lange skridt, puffende tilhøire og tilvenstre, og til dels over det fløilstæppe, ingen andre end majestæterne turde betræde, hen

7) Prinsen af Noer: Opteignelser. 1861, p. 60.

Anm.: I samme afsnit bebrejder prinsen Geheimearkivar Wegener, at han har optaget denne historie i sin »skjændige Libel«. Hvis hermed er ment A. Wegener: „Utber das wahre Verhältnis des Herzogs von Augustenburg etc.«1849, sâ findies her ingren sâdian omitale. I » Felttogene 1848. 49. 50 af Vilh. Holst, Kbhvn. 1852, nævnes, at 》Prindsen oplæaste nu en falsk Baretning af en formodentlig eftertrykt Berlings Tidende $----\ll($ p. 6). I »Felttogene i vore første Frihedsår « af Frits Holst og Axel Liljefalk, som afløser ovennævnte, findes denne passage ikke. 
til sin plads." - Men ved en anden lejlighed må fortælleren indrømme, at prinsen "var forbavsende artig " mod ham. ${ }^{8}$ )

Prinsen af Nør fortæller selv, at da de danske officerer i København blev bebrejdet, at de ikke havde hugget ham ned, undskyldte de sig med, at han "så så imponerende ud «, $\left.{ }^{9}\right)$ »og det ville derfor ikke være urimeligt, hvis man kom til den anskuelse, at en ganske almindelig lille ung lojtnant, stillet overfor den ranke og elegante fyrste, - som både kunne være "vorlaut " og charmerende, som det passede ham, og som få år i forvejen havde været general og statholder i hertugdømmerne, - ikke har vovet at fremføre en protest, ovenikøbet i en så drastisk form.

Men så er spørgsmålet: "V a r Chr. Mathiesen en ganske almindelig lille løjtnant? At han var lille, fremgår af »Generalstabens værk om den dansk-tydske Krig «, hvori det hedder: »Chr. Matthiesen var lille af væxt, men kraftig og elegant bygget. Han havde et vindende væsen og mange interesser, der forskaffede ham kammeraternes venskab på samme tid, som hans sunde fornuft, bestemte characteer og glødende fædrelandskjærlighed erhvervede ham alles højagtelse. ${ }^{10}$ )

Tilfældigvis foreligger der også et øjebliksbillede af ham. hvor den "bestemte characteer" mere konkret giver sig udtryk. I et privatbrev i januar 1838 til den unge Læssøe fortæller hans ven, Adolf Fibiger, om en kammerherre, der havde forgrebet sig på mandskabet ved flere lejligheder og fortsætter: "Rasende forbitret over, at bladene have sat ham (Rømeling) i gabestokken kommer han på parolen og insulterer sit officerskorps. Chr. Mathiesen spiller helteroller i et dramatisk selskab og har derved fået et helteydre og et Nielsen-Einar Tambeskælversk blik. Det er natur hos ham. Han ser på $R$. med det ham ejendommelige blik, denne farer i ham og dikterer ham tre dages arrest på hovedvagten. $M$. melder, at han vil klage til kongen. R. og M. hos Rex. Med helteanstand plaiderer M.

8) E. Bodenhoff: »Hofliv under trende Konger«. Uddrag af generalmajor Müllers efterladte papirer, p. 142, p. 185.

9) Optegnelser, p. 61 .

11i) 》Den dlansk-tydske Krig i Aarene 1848-50, udgivet af Generalstaben «, 1880. Nekrologen, VI, bind. 
sin sag, og han fæster sit af vor kæmpeold begejstrede, stolte øie på vor tids monark. Kongen afbryder: „Ja, men De ser også impertinent ud!« Til R.: „Se, hvor han ser på mig!« Til M.: "De går øjeblikkelig på hovedvagten. Der kan De sidde $\mathrm{i}$ fire dage, fordi De kommer her og er impertinent!« Svarer $M$. rolig og kold: „Deres Majestæt! Jeg beder allerunderdanigst om forhør og krigsret." Kongen: „Hvad! Hvad for noget! De vil ikke gå på hovedvagten? Forhør og krigsret! Ja, ja, det forstår sig, når De forlanger det. «")

Med dette kendskab til de to mænds psyke, der fredag d. 24. marts 1848 stod overfor hinanden på paradepladsen i Rendsborg, har man vel lov til at slutte, at den unge officers ord står til troende, når han hævder at have fremsat sin indvending og, efter at have fået svaret, at have sagt: "Det er logn!« — idet han meget ærligt tilføjer: „som til mig selv sagt.« Denne afsides replik i det lille drama $\mathrm{k}$ a $\mathrm{n}$ være overhørt af prinsen, men protesten mod »kongens ufrihed « blev altså ført frem fra dansk side ved denne lejlighed.

Når Prinsen af Nørs handling kunne henrive selv en så besindig mand som Heiberg til det ganske pompese, men unægtelig fortegnende digt: "Det danske flag til Prinsen af Nør." (1849) der begynder:

》Så fik du mig dla fat! Din hånd mit kors berørte, den hånd', hvormed du svor en hurtigtt krænket ed, den hănd, hvoraf dit sværd, som du med skælven førte på fơrste kampdlaig gled - « 12)

Så kan vi, der jo har begivenhederne i lidt større perspektiv, vel ikke samstemme heri, men kunne dog have onsket, at prinsens sanddruhed havde stået mål med det mod, han utvivlsomt udviste den dag, han med et par hundrede mand marcherede ind i den gamle danske fæstning ved Ejderen.

11) \$Museum «, 3. hefte, årg. 1894. D\&t er Fibiger selv, der har foretaget navneforkortelser, antagelig for at give episoden karakter af en drnamatisk scene. Når Fibiger fortæller vidiere, at »et kgl. Reskript befaler, at Sagen skulde falde bort«, stemmer dette ikke med bl. a. general Müllers ovennævnte optegnelser, hvorefter Mathiesen skulle have făet 3 mdr. i Citadellet. (p. 108). I hvert fald blev Mathiesen som en følge af stammenst $\phi$ det samme år forsit til Rendisborg.

12) J. L. Heibergs \&Poetiske Skrifter $\kappa$, 1862, 8. bd. p. 362. 